\title{
POŻEGNANIE Z ŁOTREM? YUAN SHIKAI W ŚWIETLE NOWYCH BADAŃ
}

\author{
Jakub Polit (D) http://orcid.org/0000-0002-8209-5124 \\ Uniwersytet Jagielloński w Krakowie
}

\author{
ABSTRACT \\ PARTING WITH A VILLAIN? YUAN SHIKAI IN LIGHT \\ OF NEW RESEARCH
}

Yuan Shikai, the military strongman of late Qing Empire, talented administrator and reformer, crucial figure during the 1911 (Xinhai) Republican Revolution, president with dictatorial power and, finally, a self-proclaimed emperor, is the most controversial figure of 20th-century China. After his death during the civil war that his actions provoked, historiography (communist and non-communist) portrayed Yuan as traitor and chief villain. In following years Yuan was almost unanimously denounced by Soviet (S.L. Tikhvinsky, O. Nepomnin) and Western (L. Sharman, E. Hummel) historiography. His first biography, written by Jerome Ch'en in 1960, fully upheld this portrait. Significant studies (1968 and 1977) of Ernest P. Young, based on important primary sources, went unnoticed at the time. It was also the case with Stephen McKinnon's volume on Yuan as brilliant Qing official in Tianjin and Beijing between 1901 and 1908. During the two last decades of the 20th century some smaller studies changed this unfavorable portrait. In the eyes of Marie-Claire Bergère, Madleine Ch'i, Luke Kwong and Henerietta Harrison, Yuan appears as a far-sighted statesman and defender of Chinese raison d'état. The last biography written by Patrick Fuliang Shan portrays Yuan as an extremely power-hungry and astute politician and as a conservative reformer and modernizer, at the same time. His political failure was both his personal tragedy and a catastrophe of the Chinese nation.

Keywords: 20th-century history, China, Yuan Shikai, historiography.

Słowa kluczowe: historia XX wieku, Chiny, Yuan Shikai, historiografia.

W historii nowoczesnych Chin (tej po ich „otwarciu” przez mocarstwa Zachodu w czwartej-piątej dekadzie XX wieku) nie istnieje zapewne postać bardziej zniesławiana niż on. Owszem: chińscy komuniści, jeszcze przed swym ostatecznym 
zwycięstwem, koncentrowali ogień nienawistnej propagandy na Czang Kaj-szeku' Po śmierci Mao Zedonga (którego osierocona partia nie mogła, jak należało, napiętnować za koszmar „rewolucji kulturalnej”) wcieleniem wszelkiego zła stała się obalona „banda czworga”, na czele z wdową po zmarłym dyktatorze, Jiang Qing. Wcześniej, w trakcie wielkiej wojny z Japonią (1937-1945) synonimem zdrajcy stał się przywódca kolaborującego z najeźdźcą reżimu Wang Jingwei (dawny bohater antymandżurskiej rewolucji, w pewnym momencie druga osoba w Republice Chińskiej!). Po zwycięstwie jego grobowiec - zmarł w 1944 roku - uroczyście wysadzono w powietrze. Wszyscy wymienieni mieli jednak prócz przeciwników także obrońców, a potępienie dotyczyło przede wszystkim pewnych koncepcji politycznych, które piętnowani politycy tylko symbolizowali. Jedynie Yuan Shikai - światły reformator u schyłku Cesarstwa, sprawca chwalebnej zgody narodowej w dobie Rewolucji Xinhai 1911 roku, a potem pierwszy konstytucyjny prezydent Republiki Chińskiej i niedoszły cesarz, dostąpił jednogłośnego potępienia ze strony wszystkich chyba chińskich nurtów politycznych. Nawiązywać do niego nie chciał nikt - ani wśród schodzących ze sceny dziejowej monarchistów, ani wśród republikanów, a tym bardziej w gronie kontestujących Republikę Chińską komunistów. Także przedstawiciele tak zwanej trzeciej siły, odrzucający w połowie XX wieku zarówno autorytarnych nacjonalistów z Kuomintangu (KMT, Chińska Partia Narodowa), jak i totalitarystów z KPCh, nie zapominali o wyrażeniu swej pogardy dla „zdrajcy Yuana”. Witany w chwili objęcia władzy jako nieledwie zbawca, w momencie śmierci 6 czerwca 1916 roku stał się na trwałe ,jedną z najbardziej lżonych postaci w nowoczesnej historii Chin $[\ldots]$ pozostającą symbolem wszystkiego, czym umiarkowany Chińczyk najbardziej się brzydzi"3.

Skala tej nienawiści i pogardy wobec „potrójnego zdrajcy” (miguozei), podzielanej przez członków wszelkich obozów politycznych, budzić musi zastanowienie. Prawda: Yuan w walce o władzę nie przebierał w środkach. Stosował represje wobec przeciwników politycznych, a rządził za pomocą cenzury, cynicznej propagandy i tajnej policji, opierając się przede wszystkim na siłach zbrojnych. Nie był jednak gorszy od sobie współczesnych, a w zestawieniu ze swymi następcami jego poczynania wyglądają wręcz na blade i bez znaczenia. W rzeczy samej, to co czynił Yuan, nie wytrzymuje porównania nie tylko z makabrycznymi, ludobójczymi zbrodniami Mao Zedonga, lecz także nawet z „białym terrorem” Czang Kaj-szeka. Można wręcz

${ }^{1} \mathrm{~W}$ artykule odnośnie do nazw i nazwisk chińskich stosowana będzie obowiązująca dziś powszechnie transkrypcja pinyin z wyjątkiem zakorzenionych w polszczyźnie nazw typu Pekin, Szanghaj czy Nankin oraz dwóch, mających już w naszym kraju tradycję, choć dalekich od oryginału nazwisk Sun Yatsen (zamiast Sun Zhongshan) i Czang Kaj-szek (zamiast Jiang Jieshi). Natomiast nazwiska autorów wymienionych w przypisach i tytuły ich prac zachowują swą formę oryginalną.

${ }^{2} \mathrm{O}$,trzeciej sile” por. E.S.K. Fung, In Search of Chinese Democracy; Civil Opposition in Nationalist China 1929-1949, Cambridge, MA 2000; ciągle warta uwagi jest praca najwybitniejszego teoretyka tej formacji, Zhang Junmaia alias Carsuna Changa: C. Chang, The Third Force in China, New York 1952.

${ }^{3}$ D. Lary, Yuan Shikai [w:] Encyclopedia of Modern China, vols I-IV, New York-San FranciscoNew Haven, Conn-Wateville, Maine-London 2009, vol. IV, s. 132. Autorka hasła jest jedną z najwybitniejszych znawczyń dziejów Chin dwudziestowiecznych w skali światowej. 
zasadnie wątpić, czy prezydent Chin lat 1912-1916 stosował „nowoczesny”, naprawdę masowy terror, a na pewno represjom tym brakło „naukowego” charakteru. Sprawa staje się jeszcze bardziej godna refleksji, gdy przypomni się, jak ogromnym, niekłamanym szacunkiem na arenie międzynarodowej cieszył się Yuan Shikai. Wydaje się, że pod tym względem nie dorównał mu żaden z zaledwie trzech polityków, którzy w XX wieku odegrali porównywalną rolę w dziejach jego kraju: ani Czang Kaj-szek, ani Mao, ani Deng Xiaoping. Zbliżoną renomę uzyskał tylko Zhou Enlai pod koniec swego życia, nie będąc jednak rzeczywistym liderem, ale jedynie wykonawcą wytycznych zwierzchnika dyktatora. Choć zaś istotnie można nie wierzyć, że wielu w chwili śmierci Yuana go opłakiwało (wątpliwość w wypadku dyktatorów częsta), bardzo szybko dość powszechnie zaczęto go żałować, z uwagi na załamanie się, wręcz implozję państwa po jego śmierci. Skąd więc nienawiść i pogarda?

Przypomnijmy tu w telegraficznym skrócie akt oskarżenia. Yuan, jako młody dowódca elitarnej części sił zbrojnych, miał udaremnić w 1898 roku zbawienny dla Chin program tak zwanych Stu Dni Reform, denuncjując przed reakcyjną cesarzową Cixi światłe plany cesarza Guangxu i unicestwiając tak reformy, jak i reformatorów. Wynagrodzony za zdradę rozmaitymi zaszczytami, w tym gubernatorstwem stołecznej prowincji Zhili, zachował miłą obcym najeźdźcom bierność podczas patriotycznego ruchu Yihetuanów („bokserów”, 1899-1901), przekształcając za to jedyne wartościowe siły zbrojne państwa, tak zwaną Armię Beiyang, w swą pretoriańską gwardię. Zdymisjonowany po zgonie Cixi, wypłynął znów w czasie republikańskiej Rewolucji Xinhai, gdy - mianowany premierem - miał uratować dynastię, ale zamiast tego zdradził ją, przyjmując prezydenturę z rąk wodza rewolucjonistów Sun Yatsena. Następnie zdradził i Suna, pacyfikując tak zwaną drugą rewolucję i wyrzucając „Ojca Republiki” za granicę. Nie chciał jednak bronić kraju przed mocarstwami, przyjmując w 1915 roku upokarzające Dwadzieścia Jeden Żądań Japonii. Wreszcie ostatecznie zdradził i republikę, postanawiając zostać cesarzem. Tu jednak powinęła mu się noga: stanął w obliczu ogólnonarodowego buntu i zrozpaczony umarł. Na ile te zarzuty są prawdziwe?

Najpierw wypada stwierdzić rzeczy oczywiste. Yuan zmarł, załamany i zrozpaczony, 6 czerwca 1916 roku, zapewne jednak na uremię (twierdzenia, że było to samobójstwo, są raczej nieprawdziwe, acz nader znamienne ${ }^{4}$ ). Choć w chwili śmierci był formalnie nadal prezydentem Chin, pozostawał tylko cieniem wszechwładnego do niedawna dyktatora. Jego klęska była skutkiem nieudanej próby obwołania się cesarzem, przy czym fatalna okazała się nie tyle sama idea, ile czas i sposób jej wprowadzenia w czyn. W samym pomyśle restauracji tronu nie było nic absurdalnego ani śmiesznego ${ }^{5}$. Na osiem istniejących w chwili zgonu Yuana mocarstw sześć było

${ }^{4}$ Poseł brytyjski, sir John Jordan, czerpiący wiadomości od osobistego lekarza dykatora, J.A. Bussière'a, notował: French doctor suspect poisoning. Until yesterday it seemed to be an ordinary cause of uremia (Jordan do FO, 6 VI 1916, The National Archive, London [dalej TNA], FO 371/2645/108000). Dowodów jednak brak i telegram odzwierciedla głównie pogłoski kursujące po ówczesnym Pekinie.

${ }^{5}$ Przypomnieć wypada, że jeszcze w 1922 r. attaché wojskowy Rzeczypospolitej Polskiej w Tokio, płk Antoni Alexandrowicz (wcześniej przez wiele lat zamieszkały w Mandżurii) w pisanym dla Sztabu 
monarchiami, republiki stanowiły margines, a ich przykłady (w Ameryce Łacińskiej, a może też we Francji) nie zawsze były budujące. Dla mieszkańców Państwa Środka, którzy z najstarszą na świecie monarchią pożegnali się ledwie parę lat wcześniej (w 1912 r.), republikanizm był zwykle zupełną abstrakcją. Niemniej niedługo po zgonie potężnego przywódcy upadek tronów Romanowów, Hohenzollernów i Habsburgów (wkrótce zaś także Ottomanów) zadał potężny cios zasadzie monarchicznej: właściwie wszystkie państwa powstałe po I wojnie światowej były republikami ${ }^{6}$. W Chinach bardziej od owych wypadków ideę tronu skompromitowała jednak efemeryczna, bo niespełna dwutygodniowa (1 lipca-12 lipca 1917) próba restauracji dynastii Qing ${ }^{7}$, ,po której to farsie dynastia mandżurska znalazła się w dużo gorszym położeniu niż kiedykolwiek wcześniej”". Ponieważ kolejną próbę odbudowy „,cesarstwa” (bez ogólnochińskich jednak ambicji) podjęli na terenie Mandżurii znienawidzeni Japończycy, nieco wcześniej zaś, acz raczej bezpodstawnie, oskarżano o takie plany dyktatora Chin Północnych Zhang Zuolina, będącego niepiśmiennym, bezwzględnym despotą, sięgające tronu ambicje zrównane zostały z dążeniami reakcyjnymi par excellence. Nie bez wpływu na takie mniemanie był zapewne fakt, iż w świecie zachodnim jedyną udaną próbą wskrzeszenia monarchii po II wojnie światowej (która zmiotła kolejne trony) była Hiszpania generała Franco, czyli państwo wodza uważanego - w przeciwieństwie do „nowoczesnych” tyranów, jak Mussolini i Hitler - za przywódcę , anachronicznego”. Człowiek dopiero co sławiony za nowatorską koncepcję państwa okazał się nagle ,atawistycznym produktem starożytnego społeczeństwa, który pojawił się zbyt późno w nowoczesnym świecie"

Do Yuan Shikaia nikt więc nie chciał nawiązywać. Watażków, którzy po śmierci dyktatora rozszarpali Chiny, dawnych generałów jego Armii Beiyang, zraziły do wodza jego dynastyczne plany; poprzednio liczyli na odziedziczenie po nim stanowiska głowy państwa. Zmiatający umundurowanych tyranów Kuomintang, wiedziony najpierw przez „Ojca Republiki” Sun Yatsena, a potem Czang Kaj-szeka, miał z Yuanem znacznie bardziej fundamentalne, zadawnione porachunki. Sun, proklamowany tymczasowym prezydentem w Nankinie 29 grudnia 1911 roku, w dobie pierwszych,

Generalnego RP raporcie za główny warunek przywrócenia ładu w Państwie Środka (przed wkroczeniem korpusu interwencyjnego złożonego z kontyngentów mocarstw) uważał „wskrzeszenie monarchii w Chinach" ([płk. A. Alexandrowicz], Historyczny szkic wydarzeń w Chinach poczawszy od $1917 r$. do 1 stycznia 1922 r., 16 II 1922, Archiwum Akt Nowych, Warszawa, OIISzG-616,65, s. 24).

${ }^{6}$ Królestwo Serbów, Chorwatów i Słoweńców (SHS) było kontynuacją przedwojennej Serbii, a Irlandia (której konstytucja nie mówiła zresztą, czy kraj jest monarchią, czy republiką) de iure dominium brytyjskim.

${ }^{7}$ Mimo funkcjonującej w większości języków europejskich nazwy „restauracja mandżurska” (Manchu Restoration, la restauration mandchoue) właściwie wszyscy uczestnicy przewrotu, prócz nieletniego cesarza Puyi, byli etnicznymi Chińczykami Hanami.

${ }^{8}$ R.L.P. Weale, The Fight for the Republic in China, New York 1917, s. 368; opis przedsięwzięcia w sławnych pamiętnikach głównego bohatera: $\mathrm{Pu}$ Yi, Byłem ostatnim cesarzem Chin, t. I, tłum. J. Mach, Łódź 1988, s. 71-79. Samo wydarzenie warte jest osobnej monografii.

${ }^{9}$ F. Farjenel, A travers la révolution chinoise. Mes séjours dans le sud et dans le nord. L'évolution des moeurs. Entretiens avec les chefs des partis. L'Emprunt inconstitutionel. Le coup d'état, Paris 1914, s. 293. Praca Farjenela, wyjątkowa w publikacjach przed 1918 r. w swym krytycyzmie wobec Yuana, po tej dacie zaczęła być chętnie cytowana. 
zawrotnych sukcesów rewolucji Xinhai, w marcu zrzekł się bowiem swego tytułu na rzecz właśnie generała. Ponieważ potem pożałował tego kroku i latem 1913 roku wszczął krótkotrwałą i całkowicie nieudaną rewoltę, postępowanie Yuana odebrane zostało jako perfidna gra dwulicowca, który rozmyślnie oszukał szlachetnego rewolucjonistę. Gdy zaś, po kruchym zjednoczeniu kraju przez KMT, zmarły Sun został otoczony w Chinach oficjalnym kultem, interpretacja ta stała się podręcznikowym kanonem ${ }^{10}$. Komunistyczna Partia Chin, stająca się - po przelotnej współpracy w latach 1923-1927 - śmiertelnym wrogiem Kuomintangu, interpretacji tej bynajmniej nie podważyła. Zwolennicy Mao Zedonga w niewiele mniejszym bowiem stopniu niż Czang Kaj-szek nawiązywali do idei Suna, ogłaszając własną partię jego rzeczywistymi spadkobiercami. W tej sytuacji oskarżanie adwersarzy o podobieństwo do arcyzdrajcy stało się nader wygodnym chwytem retorycznym. W 1946 roku czołowy wówczas propagandysta KPCh Chen Boda opublikował dzieło pod chwytliwym tytułem Yuan Shikai, czołowy uzurpator narodowy ${ }^{11}$. Pod maską owego Uzurpatora (qieguodadao) atakowano naturalnie Czang Kaj-szeka, do którego zmarły przed trzema dekadami polityk miał być rzekomo podobny; wcześniej partia zarzucała Czangowi, iż „wasze okrucieństwo w rozprawie z patriotycznym ruchem ludowym jest takie samo, jak u Yuan Shikaia"12. Po zwycięstwie Chen nie potrzebował już alegorii, tworząc kolejny paszkwil Czang Kaj-szek, wróg chińskiego narodu ${ }^{13}$.

Zarówno w Republice Chińskiej - ograniczonej po 1949 roku do Tajwanu - jak i w szarpanej rewolucyjnymi konwulsjami ChRL rzetelna dyskusja nad Yuanem była więc niemożliwa. Pozostawali chińscy i niechińscy badacze na emigracji. Ci jednak stali się więźniami dwubiegunowego schematu KPCh-KMT (nieliczni działacze „trzeciej siły” opowiedzieli się zwykle za jedną ze stron), dla „,anachronicznego dyktatora" nie było w nim miejsca. W historiografii dominowali bez reszty zwolennicy Sun Yatsena, niezależnie od tego, czy postrzegali go jako fundatora kontynuowanej na Tajwanie Republiki Chińskiej, czy prekursora komunistycznej Republiki Ludowej. Jeszcze w latach 30. Lyon Sharman, skądinąd jedna z bardziej powściągliwych wielbicielek „Ojca Republiki”, stwierdziła, iż generalski oponent Suna „,uczynił się małym Mussolinim w epoce, gdy Mussolini nie wyłonił się jeszcze jako precedens" ${ }^{\prime 14}$. Wywody takie czyniły z konserwatysty Yuana prekursora totali-

${ }^{10}$ O kulcie Suna po jego śmierci por.: Chen Yunqian, Sun Yat-sen jako symbol w pamięci politycznej klas niższych we współczesnych Chinach, „Azja-Pacyfik” 2011, nr 14, Toruń-Warszawa, s. 49-69.

${ }^{11}$ Chen Boda, Jieshaoqieguodadao Yuan Shikai, Zhangjiakou 1946. Praca wydana została w pierwszym roku rozpalającej się wojny domowej w opanowanym przez komunistów Kałganie (Zhangjiakou). Po zwycięstwie komunistów w 1949 r. potomkowie Yuana byli w ChRL represjonowani i poniewierani.

${ }^{12}$ Cyt. za: E. Snow, Red Star over China, New York 1936, s. 400. Cytat pochodzi z nominalnego oświadczenia warlorda Zhang Xuelianga, autora sławnego zamachu z Xi'anu (1936), niemniej autorami manifestu byli niemal na pewno komuniści (konkretnie Zhou Enlai).

${ }^{13}$ Korzystałem z wydania rosyjskiego: Czan Kaj-szy, wrag kitajskogo naroda, Moskwa 1950. Po oddaniu Mao wielkich usług w oczernianiu KMT Chen Boda został w czasie „rewolucji kulturalnej’ zdemaskowany przez własną partię jako ,,antykomunistyczny element kuomintangowski, wrogi agent i rewizjonista".

${ }^{14}$ L. Sharman, Sun Yat-sen: His Life and Meaning, A Critical Biography, Stanford, CA 1934, reprint 1968, s. 203. Praca pani Sharman, krytyczna wobec kultu Suna w Chinach, była do lat 70. XX w. może najlepszą anglojęzyczną biografią tej postaci. 
taryzmu. Opublikowany w czasie II wojny światowej monumentalny (i do dziś użyteczny) słownik biograficzny wybitnych mieszkańców Chin z czasów ich ostatniej cesarskiej dynastii podsumował dyktatora nader surowo. Przyznawano wprawdzie, iż „mimo swych oczywistych mankamentów, Yuan był człowiekiem wielkiej energii, wytrwale zajmującym się sprawami państwowymi”. Niemniej „nie był zainteresowany demokratyczną formą rządów, podobnie jak jego poplecznicy, czy to oficerowie znani potem jako militaryści Beiyang, czy to urzędnicy odziedziczeni po starym reżimie"15. W społeczeństwie uznającym stosunek do demokracji za miarę wartości polityka była to charakterystyka druzgocąca.

W 1961 roku nakładem oficyny George Allen \& Unwin ukazała się pierwsza w języku europejskim biografia pierwszego prezydenta Chin, która na długo ukształtowała opinie świata naukowego na jego temat. Za jednym zamachem przekreśliła ona wszystkie, nader pochlebne dla Yuana, opinie współczesnych prezydentowi europejskich i amerykańskich polityków oraz dyplomatów, w ogromnej większości od dawna już zresztą nieżyjących. Sam jej tytuł Yuan Shih-k'ai 1859-1916. Brutus sięgający po purpurę ${ }^{16}$ ustawiał głównego bohatera jeszcze przed lekturą.

Autor monografii, Chen Zhirang znany jako Jerome Ch'en, urodzony w 1919 roku w Chengdu (prowincja Sichuan), wykształcenie zdobył w Republice Chińskiej na uniwersytetach w Tianjinie i w Kunmingu. Ostatnia z tych uczelni w dobie wojny chińsko-japońskiej uchodziła za oazę wolnej myśli, ale tamtejsza mocno lewicująca profesura kultywowała tradycyjne poglądy na temat Yuana. Młody człowiek kontynuował studia w Anglii, w London School of Economics, pod kierunkiem samego Friedricha Hayeka. Po krótkim zatrudnieniu w chińskiej sekcji BBC i dłuższym nauczaniu dziejów Państwa Środka na uniwersytecie w Leeds wyjechał do Kanady, gdzie zdobył sobie międzynarodową sławę jako znawca chińskiej historii na York University w Toronto ${ }^{17}$.

Biografia Yuana była pierwszą wielką historyczną pracą Ch'ena; być może potem sformułowałby ją inaczej. Znakomicie napisana i potoczysta, miała niemal cechy paszkwilu. Jej autor stworzył niezwykle plastyczny obraz cynicznego do szpiku kości politycznego kameleona, którego głównym rysem była „nienasycona żądza władzy"18. Jeśli chiński przywódca nie był idealnym odwzorowaniem szekspirowskiego arcyłotra Ryszarda III, (,zabijającego ze śmiechem na ustach”), to tylko dlatego, że niczym ojcowie chrzestni mafii pozostawał absolutnie obojętny, eliminując ludzi szkodliwych dla jego interesów. Ukształtowany w dekadenckiej monarchii mandżurskiej, nieznający żadnych zasad moralnych i z powodu absolutnej bezideowości niezdolny do stworzenia nowoczesnej partii politycznej, ów chiński Machiavelli (porównanie Ch’ena) „,był typowym produktem Chin po 1895 roku - niezdolnych

${ }^{15}$ Eminent Chinese of the Ch'ing Period (1644-1912), vol. II, ed. A.W. Hummel, Boston 1944, s. 953.

16 J. Ch'en, Yuan Shih-k'ai 1859-1915: Brutus Assumes the Purple, London 1961.

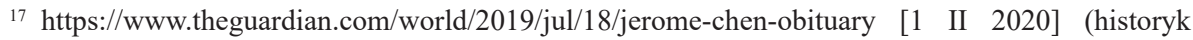
zmarł 17 VI 2019 r. na krótko przed setnymi urodzinami). Autorką nekrologu jest znakomita kanadyjska badaczka Chin Diana Lary.

18 J. Ch' en, op. cit., s. 256. 
do obrony, zubożałych oraz pogrążonych w moralnym i ideowym chaosie"19. Był zawodowym wojskowym, ale - symulując chorobę - odmówił pójścia w bój przeciw Japończykom w 1894 roku; nigdy też nie powąchał prochu w żadnej z bitew. Sądził, że pozyska mocarstwa dla swych sięgających tronu planów, wysługując się im, ale nie docenił faktu, iż Japończycy, którzy przyczynili się do jego ostatecznej klęski, są jeszcze podlejsi niż on. Ch'en nie negował biegłości Yuana w politycznych intrygach ani jego przenikliwości i uzdolnień. Wskazywał jednak, że wykorzystał on je w złej sprawie. Podtrzymał w całej pełni oskarżenie, iż generał był głównym sprawcą katastrofy reformatorów w 1898 roku, kiedy to (niczym Judasz) „złożył pocałunek śmierci na policzku Stu Dni Reform”, a u zwycięskiej cesarzowej wdowy „pozostał głównym oprawcą na jej usługach aż do jej śmierci w 1908 roku"20. Jako wicekról stołecznej prowincji Zhili przeprowadził wprawdzie wiele reform i stworzył pierwsze w Chinach nowoczesne siły zbrojne, ale w celu masakrowania rodaków; ,jego armia była stworzona do obrony [kraju], ale nie dla jej UŻYWANIA w celu obrony"21. Mimo wszystko jednak, gdyby zmarł przed rewolucją 1911 roku - kiedy to zdradził dynastię, tak jak pięć lat potem miał zdradzić republikę - „byłby mniej ważną postacią w historii, ale o wiele lepszym człowiekiem"22. Jako nieuleczalny megaloman wybrał jednak samozniszczenie, pociągając za sobą w przepaść kraj, który jego generałowie rozszarpali.

Jerome Ch'en nie korzystał z prac autorów rosyjskojęzycznych; zresztą w jego czasach przepływ myśli (nie mówiąc o kontaktach osobistych) między badaczami sowieckimi i zachodnimi był nader ograniczony, choć stan ten powoli zaczął ulegać zmianie $^{23}$. Jego następcy mogli jednak w owych dziełach znaleźć pełne potwierdzenie, jeśli nie podkreślenie, stworzonego czarnego obrazu. Wszak już Lenin dojrzał w Yuanie przedstawiciela sfery

której działacze [...] najbardziej skłonni są do zdrady; wczoraj bali się oni bogdychana [cesarza - J.P.] i korzyli się niewolniczo przed nim, potem, gdy zobaczyli siłę, kiedy poczuli zwycięstwo rewolucyjnej demokracji, zdradzili bogdychana, jutro zaś będą zdradzać demokrację dla ugody z jakimś dawnym czy nowym ‘konstytucyjnym’ bogdychanem ${ }^{24}$.

Piszący w apogeum stalinizmu Gerontij Jefimow podsumował swą ocenę chińskiego polityka słowami „Yuan Shikai, kat i zdrajca, 'zasłużył sobie' całą swoją działalnością na uznanie świata kapitalistycznego" ${ }^{25}$. Po XX Zjeździe KPZR oceny te

19 Ibidem, s. 256-257.

${ }^{20}$ Ibidem, s. 62.

${ }^{21}$ Ibidem, s. 195.

22 Ibidem, s. 257.

${ }^{23}$ Por. uwagi Gilberta Rozmana we wstępie do: G. Rozman, Soviet Studies of Pre-Modern China, Assessments of Recent Scholarship, Ann Arbor 1984 (konkluzja: prace przydatne, ale trudno dostępne na Zachodzie).

${ }^{24}$ W.I. Lenin, Diemokratia i narodniczestwo w Kitaje [w:] idem, Soczinenija, t. 18, Moskwa 1948, s. 145. Nawiasem mówiąc, wedle Lenina Yuan był przedstawicielem „liberalnej burżuazji” (ibidem, s. 148).

${ }^{25}$ G. Jefimow, Zarys nowożytnej $i$ wspótczesnej historii Chin, thum. M. Derenicz, Warszawa 1952, s. 187. 
uległy jedynie niewielkiej (jeśli jakiejkolwiek) korekcie. W wydanej w 1959 roku, skądinąd cennej faktograficznie, monografii Stu Dni Reform Siergiej Leonidowicz Tichwinskij podtrzymał w całej rozciągłości czarną legendę Yuana jako czołowego sprawcy fiaska podjętej ówcześnie próby modernizacji. Autorzy tej ostatniej, z Kang Youweiem na czele, mimo wytykanych im obowiązkowo „burżuazyjnych ograniczeń", zawinili przede wszystkim szlachetną naiwnością, składając swój los w ręce perfidnego dwulicowca ${ }^{26}$. W swych późniejszych pracach Tichwinskij, powtórzywszy tezy o zdradzie Yuana w 1898 roku, skupił się na podkreśleniu jego roli jako „kreatury feudalnej reakcji chińskiej i międzynarodowego [?] imperializmu"27, człowieka, który podczas swej prezydentury „dążył do zdławienia ruchu demokratycznego, do zlikwidowania wszystkich zdobyczy politycznych wywalczonych przez burżuazję przy poparciu szerokich mas ludowych, do przywrócenia w Chinach nieograniczonego panowania obszarników i do zdobycia dla siebie cesarskiego tronu"28. Nawet po upadku ZSRR i częściowym uwolnieniu nauki rosyjskiej od dogmatycznego kagańca (poprawa stosunków z Pekinem też odegrała swoją rolę) poglądy owe nie zanikły. Zoja D. Katkowa i Jurij Czudodiejew, odnotowując opór prezydenta „i jego grupy społecznej” wobec agresywnych poczynań Japonii (w porównaniu z poprzednią epoką była to i tak konstatacja in plus), uznawali go za „nader charakterystyczny dla dzierżących władzę konserwatywnych nacjonalistów”, ponieważ ,japońska agresja jawiła się im jako groźba i 'wyzwanie' dla ich monopolu władzy”29. W swej (notabene ciekawej) syntezie schyłku cesarstwa chińskiego Oleg Jefimowicz Niepomnin podsumował historyczną rolę Yuana słowami: „ów dwulicowiec i karierowicz udawał zagorzałego reformatora" ${ }^{30}$.

Fatalny obraz Yuana skamieniał w syntezach i podręcznikach. Nader nieliczne sygnały sugerujące jego zmianę wchłaniane były przez dotychczasowe schematy. W 1966 roku George T. Yu w studium o wczesnej historii Kuomintangu wskazał na błędy jego przywódców i to, że „ostateczna wina za jego upadek [w 1913 r.] musi być przypisana samej partii”. Yu podkreślił, iż w 1914 roku Sun Yatsen oferował Japończykom ekonomiczne przywileje w Chinach jako zapłatę za pomoc w obaleniu swego przeciwnika, podczas gdy Yuan, próbując przeciwstawić się rok potem ultimatum Tokio znanemu jako Dwadzieścia Jeden Żądań, „stał się symbolem walki z japońską agresją"31.

${ }^{26}$ S.L. Tichwinskij, Dwiżenije za reformy w Kitaje i Kan Ju-wej, Moskwa 1959.

${ }^{27}$ Przypomnieć warto, że centralnie sterowany „międzynarodowy imperializm” odgrywał w komunistycznej doktrynie taką rolę, jak „światowe żydostwo” w doktrynie narodowych socjalistów.

${ }^{28}$ Historia nowożytna Chin, red. S.L. Tichwiński, thum. M. Wolska, Warszawa 1979, s. 578 (pierwszy cytat) i 582 (drugi). Tom jest pracą zbiorową (bez podania - jak często w publikacjach sowieckich - nazwisk poszczególnych autorów), wydaje się jednak oczywiste, że partie dotyczące Yuana Tichwinskij napisał sam.

${ }^{29}$ Z.D. Katkowa, J. Czudodiejew, Kitaj-Japonia: liubow ili nienawist? K problemie ewolucji socjalno-psichologiczeskich i politiczeskich stiereotypow wzaimowospijatija, Moskwa 2001, s. 146.

${ }^{30}$ O.J. Niepomnin, Istorija Kitaja. Epocha Cin, XVII - naczało XX wieka, Moskwa 2005, s. 488.

${ }^{31}$ G.T. Yu, Party Politics in Republican China. The Kuomintang, 1912-1924, Berkeley 1966, s. 112, $131,138$. 
W wydanej w 1970 roku monografii chińskiej polityki zagranicznej w czasie I wojny światowej (dla Państwa Środka nie była to „Wielka wojna”, ale determinowała poczynania dominujących nad nim mocarstw) Madleine Ch'i doceniła zręczność dyplomatyczną dyktatora, umiejętnie kontrującego zakusy zagranicznych potęg, którym bynajmniej nie był powolny. Bodaj po raz pierwszy podkreśliła też dobitnie, iż decydujący dla jego cesarskich ambicji cios zadały nie czynniki wewnętrzne, a poczynania japońskie. Dostrzegła, iż w dobie osławionych Dwudziestu Jeden Żądań ,zyski, jakie Japonia uzyskała kosztem Chin, nie były tak wielkie, jakimi się wydawały na papierze" ${ }^{32}$. Zauważyła w końcu, iż prezydent postrzegany jest wyłącznie przez pryzmat finalnej katastrofy. „Katastrofalna klęska Yuana przypieczętowała jego los w historiografii chińskiej. Często jest opisywany jako zdrajca republiki i niewolnik własnych ambicji. Rzadko się słyszy pochwałę jego energii, jego przenikliwości lub jego zdolności administracyjnych przed niemądrą próbą wskrzeszenia monarchii”"33. Mimo tych niebanalnych spostrzeżeń końcowy werdykt był negatywny. Odbudowę cesarstwa autorka uznała za zbrodniczy absurd, a zmierzające ku niej poczynania Yuana za główną przyczynę rozpadu państwa na władztwa warlordów.

Jednolicie czarny obraz dyktatora powinien był ulec zdecydowanej korekcie za sprawą studiów znakomitego badacza z University Michigan Ernesta P. Younga. W rzeczy samej, z dzisiejszej perspektywy, można wyrazić zdumienie, że tak się nie stało. Young nie napisał biografii Yuana. W swej pierwszej monografii (Yuan Shih-k'ai Rise to Presidency) zajął się rolą odegraną przez generała w republikańskiej Rewolucji Xinhai. W drugiej, będącej studium jego prezydentury (The Presidency of Yuan Shih-k'ai), kreślił nie tyle polityczny życiorys jednostki, ile zmagania różnych nurtów politycznych w latach 1912-1916 oraz ich wpływ na ówczesne funkcjonowanie państwa.

Jak podkreślił recenzent monografii The Presidency of Yuan Shih-k'ai, „Ernest P. Young nie zajmuje się zbytnio mankamentami charakteru Yuana, o których napisano tak wiele, ale próbuje ukazać, jak Yuan postrzegał problemy stojące przed Chinami oraz wewnętrzne sprzeczności w jego próbach ich rozwiązywania" ${ }^{34}$. Podejście takie, będące obowiązkiem każdego rzetelnego biografa, w studiach nad Yuanem oznaczało swoisty przełom.

W swej rozprawie o kompromisie wieńczącym rewolucję Xinhai Young uderzył w dotychczasowy dogmat, iż Yuan rozstrzygnięcie negocjacji na swoją korzyść zawdzięczał przede wszystkim perfidnym intrygom oraz szantażowi. Wszak przed wybuchem był politykiem bezsilnym, traktowanym na dworze jako persona non grata.

Tym pojedynczym czynnikiem, który najlepiej wyjaśnia wzlot Yuana podczas rewolucji, jest fakt, że wielu ludzi, reprezentujących szerokie spektrum opinii, w rzeczy samej pragnęło, aby wziął na siebie odpowiedzialność za przeprowadzenie Chin przez przyspieszony rewolucją

${ }^{32}$ M. Ch'i, China Diplomacy 1914-1918, Cambridge, MA 1970, s. 60.

${ }^{33}$ Ibidem, s. 83.

34 J.E. Sheridan [recenzja z: E.P. Young, The Presidency of Yuan Shih-k'ai: Liberalism and Dictatorship in Early Republican China, Ann Arbor 1977], „The American Historical Review”, February 1978, vol. LXXXIII, no. 1, s. 254. 
kryzys. [...] Rewolucjoniści bardzo prędko uznali, że współpraca z Yuanem jest kluczowa dla powodzenia ich planów ${ }^{35}$.

Korzystając ze źródeł chińskich i brytyjskich (najlepszych z zagranicznych), badacz wykazał, że w żadnym ze zgromadzeń w zrewoltowanych prowincjach przeciwnicy takiej kooperacji nie mieli większości. Następnie przekonująco obalił opinio communis, iż mianowany cesarskim premierem Yuan mógł bez trudu spacyfikować zbuntowane Południe. Podległa generałowi Armia Beiyang, acz wyborowa, była stosunkowo nieliczna; co gorsza część jej oficerów, wyedukowanych w Japonii, nie w Chinach, nie była wcale ślepo wierna swemu wodzowi. Armia ta mogła zapewne wygrać każdą bitwę, ale nie gwarantowała trwałej pacyfikacji szeroko rozlanego powstania. Cytując świadectwa brytyjskie i japońskie, konstatował, iż „Yuan musiał zrozumieć, że chociaż prawdopodobnie mógł zdobyć Wuchang [stolicę rebeliantów - J.P.], to rewolucyjna armia jako całość nie może zostać łatwo zmieciona i że [...] kompromis z Południem jest konieczny" ${ }^{\prime 36}$. W sumie generał był bardziej mistrzem realizmu politycznego, opartego na kompromisie, niż oszustwa i intrygi.

W kolejnym, monumentalnym studium Ernest P. Young ukazał dotychczasowego antybohatera jako autentycznego, acz autorytarnego reformatora, którego celem było stworzenie nowoczesnego państwa. Pod tym względem jego działania w czasach przed rewolucją Xinhai i po niej wykazywały uderzające continuum. Yuan, nie będąc demokratą, nie był żadnym zakapturzonym zwolennikiem starego porządku czy „feudalizmu”. Wierzył w koleje, telegrafy i nowoczesną edukację typu zachodniego. W tym modernizacyjnym programie i otwartości na pomoc zagraniczną przypominał, o paradoksie, swego największego przeciwnika, Sun Yatsena. Choć jednak dzięki zręcznej dyplomacji potrafił do czasu (to znaczy do wybuchu absorbującej mocarstwa wojny światowej) pozyskiwać pieniądze od zagranicznych potęg, brakowało mu wewnętrznego ugruntowania własnej władzy. Zniknięcie tronu spowodowało bowiem usunięcie uznawanego przez wszystkich autorytetu, dotychczasowa warstwa rządząca (określana w historiografii zwykle anglojęzycznym terminem gentry) miała zaś interesy stricte prowincjonalne i była $\mathrm{z}$ tego powodu wroga centralizacyjnym dążeniom prezydenta. Ten ostatni nie mógł się przy tym odwołać do partii głoszących program ogólnonarodowy. Takie bowiem w tym czasie nie istniały oprócz rewolucyjnej, sunyatsenowskiej Chińskiej Partii Narodowej, czyli Kuomintangu. Wszelako właśnie kuomintangowcy byli najzacieklejszymi wrogami Yuana ${ }^{37}$.

By kontynuować reformy i uniezależnić się od mocarstw, prezydent potrzebował środków, które mogła zapewnić tylko dalsza centralizacja państwa. Bezpośrednim rezultatem republikańskiej rewolucji stały się bowiem ruchy odśrodkowe, skutkujące odpadnięciem etnicznie obcych kresów (Mongolia Zewnętrzna, Tybet), a także drastycznym spadkiem dochodów uzyskiwanych z prowincji. Yuan podjął w tej

${ }^{35}$ E.P. Young, Yuan Shih-k'ai Rise to the Presidency [w:] China in Revolution: The First Phase, 1911-1913, ed. M.C. Wright, New Haven-London 1968, s. 420 i 442.

${ }^{36}$ Ibidem, s. 425.

${ }^{37}$ E.P. Young, The Presidency of Yuan Shih-k'ai: Liberalism and Dictatorship in Early Republican China, Ann Arbor 1977, passim. 
kwestii działania, które zaczęły dawać rezultaty, ale owoców tych nie zdołał skonsumować z powodu zbyt krótkiego trwania jego władzy. Jego program potrzebował czasu i cierpliwości. Tych zabrakło z powodu zaabsorbowania europejską wojną tych mocarstw, które uważały go za gwaranta chińskiej stabilizacji oraz z powodu perfidnej akcji Japończyków. Jednocześnie rewolucjoniści bezustannie wzywali do działań przeciwko niemu. Ponieważ w oczach kręgów opiniotwórczych (właśnie gentry) prezydent miał ,papiery nie w porządku”, jako wychodzący z pogardzanego, wojskowego środowiska, jedynym wyjściem dla niego okazywało się zapoczątkowanie własnej dynastii. „Jego zasadniczą przesłanką było założenie, iż szerokie rzesze narodu nie mają pojęcia, co znaczą republikanizm, równe prawa, reprezentatywny rząd, a są jedynie przez to dezorientowane. Co do tego Yuan miał bez wątpienia rację" ${ }^{38}$.

Także zarzut, iż dyktator był „ojcem warlordów”, winnym późniejszego rozpadu kraju na niemal samodzielne satrapie, był tylko częściowo prawdziwy. Owszem, pacyfikując kraj, prezydent przydał prowincjonalnym gubernatorom, wywodzącym się zresztą z szeregów jego Armii Beiyang, prerogatywy wojskowe, co potem okazało się fatalne. Miało być to jednak uprawnienie przejściowe, którego miano gubernatorów pozbawić. Dyktator „zredukował liczbę żołnierzy i próbował zreorganizować wojsko jako narzędzie siły narodowej pod kontrolą centrum. [...] Największym wkładem Yuana do okresu warlordowskiego była jego porażka odnośnie do wcielenia w życie własnego programu" ${ }^{\prime 3}$.

Yuan przegrał częściowo dlatego, że jego wizja modernizacji była tak wąska. (Dziś powiedzielibyśmy, iż nie mógł się odwołać do partii masowej ani do radia, nie mówiąc już o telewizji). Przegrał jednak głównie z powodu czynników losowych (takich jak spętanie życzliwych mu mocarstw wybuchem wojny światowej) i z powodu poczynań Japończyków. Young, nawiasem mówiąc, nigdy nie postawił pytania nader prostego: jeśli dobre stosunki prezydenta z obcymi ambasadami (głównie brytyjską) sprzyjający rewolucjonistom badacze określali mianem zdradzieckich, to jak określić pełną współpracę tychże rewolucjonistów z Japonią, będącą w owym czasie największym zagrożeniem dla suwerenności Chin? ${ }^{40}$

Długofalowo prace Younga okazały się przełomowe, zapoczątkowując zmianę trendów badawczych. Doraźnie jednak zmieniły niewiele w podręcznikach. W tych nadal postrzegano dzieje dwudziestowiecznych Chin przez dychotomiczny schemat KMT-KPCh, a obie te siły potępiały Yuana.

W latach 80 . drogą wytyczoną przez Younga, ale ogniskując badania na wcześniejszej dekadzie, podążył ówczesny profesor State University Arizona Stephen R. McKinnon. Szlak przetarł artykułem The Peiyang Army: Yuan Shih-k'ai and the Origins of Chinese Warlordism, ogłoszonym w prestiżowym „Journal of Asian Studies”. Dowiódł w nim, że będąca w znacznej mierze dziełem Yuana słynna Armia

${ }^{38}$ E.P. Young, The Hung-hsien Emperor as Modernizing Conservative [w:] The Limits of Change: Essays on Conservative Alternatives in Republican China, ed. Ch. Furth, Cambridge, MA-London 1976, s. 174.

${ }^{39}$ E.P. Young, The Presidency of Yuan Shih-k'ai, s. 242.

${ }^{40}$ Przyznać trzeba, iż pytanie takie postawili po prawie ćwierćwieczu wspomniani badacze rosyjscy: Z.D. Katkowa, J. Czudodiejew, op. cit., s. 156 i 161. 
Beiyang nie była w żadnym razie - jak bezrefleksyjnie dotąd przyjmowano - quasi-prywatną formacją w ręku generała, przemyślnie finansowaną z prowincjonalnych funduszy w ten sposób, by zminimalizować jej zależność od rządu centralnego. $\mathrm{W}$ istocie - prócz 5. dywizji - na utrzymanie tych wojsk łożył ogromne sumy rząd pekiński. Yuan poprzez różne koneksje i personalną żonglerkę wśród oficerów zapewniał sobie wprawdzie lojalność generalicji, lecz poczynania te koncepcyjnie nie wychodziły poza ówcześnie przyjęte zwyczaje, były tylko bardziej wyrafinowane i skuteczne ${ }^{41}$. Ustalenia te zostały wkrótce potwierdzone przez innych badaczy, przede wszystkim Edmunda S.K. Funga ${ }^{42}$. Ten ostatni podkreślił, iż z porady Yuana „rząd chiński nie uciekał się do żadnych zagranicznych pożyczek w obawie przez cudzoziemską kontrolą armii" ${ }^{43}$.

Podsumowaniem badań McKinnona stała się monografia Power and Politics in Late Imperial China, będąca w istocie swoistą biografią "przedprezydenckiego" okresu życia Yuana. Amerykański badacz nakreślił panoramę imponujących reform lat 1901-1908, często deprecjonowanych wcześniej jako „rzekome”44. „Jako generalny gubernator [prowincji] Zhili w Tianjinie i wysoki urzędnik w Pekinie od 1901 do 1907 r., Yuan był w stanie działać efektywnie i symultanicznie na szczeblu xian [powiatu], prowincjonalnym oraz centralnym. Było to kluczowe w odniesieniu do użycia reform jako źródła siły politycznej”45. Zastanawiając się nad przyczynami mrocznej historiograficznej legendy swego bohatera, McKinnon (nawiasem mówiąc, niezbyt go lubiący jako człowieka) doszedł do oczywistych wniosków.

Yuan był z natury człowiekiem skrytym, starającym się pozostawić niewiele śladów w osobistych papierach. Owa trudność przyczyniła się do postrzegania Yuana jako postaci kontrowersyjnej. Na nieszczęście dla niego, bez dokumentów świadczących o czymś przeciwnym, lawiny plotek stworzyły niewzruszony obraz Yuana jako legendarnego łotra chińskiej historiografii. Niemniej z jego działań, z cudzych badań i wnikliwego wczytywania się w oficjalne oświadczenia Yuana i z tego, co wydaje się najbardziej zasługiwać na zaufanie ze świadectw prywatnych, wnioskuję, że Yuan widział ratunek dla narodu chińskiego w stworzeniu silnego, scentralizowanego państwa będącego w stanie powstać z kolan i oprzeć się cudzoziemcom. Dla osiągnięcia tego celu pragnął zastosować najszybsze i najbardziej skuteczne środki, nawet gdyby prowadziło to do upokarzających kompromisów z mocarstwami. Yuan postrzegał siebie jako silnego gracza, niezbędnego do stworzenia silnego, scentralizowanego państwa - zarówno jako premier w czasach Qingów, prezydent Republiki Chińskiej, jak i cesarz swej własnej dynastii Hongxian ${ }^{46}$.

${ }^{41}$ S.R. McKinnon, The Peiyang Army: Yuan Shih-k'ai and the Origins of Chinese Warlordism, „Journal of Asian Studies” 1973, vol. XXXII, no. 3, s. 405-422.

${ }^{42}$ E.S.K. Fung, The Military Dimension of The Chinese Revolution: The New Army and its Role in the Revolution of 1911, Canberra 1981, s. 53-58.

43 Ibidem, s. 54.

44 Por. W. Rodziński, Historia Chin, Wrocław 1992, s. 539 („polityka tak zwanych reform”). Synteza Rodzińskiego zawiera wszystkie możliwe stereotypy na temat Yuana, podane w dodatku w sugestywnie obelżywej formie.

${ }^{45}$ S.R. Mc Kinnon, Power and Politics in Late Imperial China: Yuan Shi-kai in Beijing and Tianjin, 1901-1908, Berkeley-Los Angeles-London 1980, s. 214.

46 Ibidem, s. 221-222. 
McKinnon ostatecznie udowodnił, iż Yuan był główną siłą sprawczą reform u schyłku cesarstwa, zarówno politycznych (postulat zwołania lokalnych zgromadzeń prawodawczych), wojskowych (nowoczesna Armia Beiyang), jak i edukacyjnych (memoriał o szkodliwości tradycyjnego systemu egzaminacyjnego, zakończony zniesieniem tegoż). Pod jego kierunkiem fenomenalnie wzrosła liczba wzorowanego na zachodnim szkolnictwa podstawowego (1902 - tysiąc osób, 1908 - 148 tysięcy). Badania amerykańskiego historyka potwierdzone zostały w pełni przez jego naśladowców, sięgających do nowych źródeł; w Polsce (odnośnie do innowacji w wojsku) uczynił to już w następnym stuleciu Mateusz Nowikiewicz ${ }^{47}$. Ponieważ jednak o smoliście czarnym wizerunku Yuana w historiografii decydowały nie jego poczynania u schyłku Cesarstwa, ale lata 1911-1916, badania te tylko w niewielkim stopniu zmieniły dotychczasowy wizerunek.

Jednocześnie jednak stało się jasne, jakim nonsensem było postrzeganie Yuana jako polityka korzystającego „z pełnego poparcia i pomocy wszystkich mocarstw” w celu „zagwarantowania wszystkich interesów imperializmu obcego w Chinach"48. Owszem: opublikowana w 1978 roku lapidarna, źródłowa rozprawa Chan Lau Kit-chinga ukazała, iż relacje generała z przywódcami społeczności zachodniej w Chinach nacechowane były wzajemnym szacunkiem, wynikłym $\mathrm{z}$ realnej wspólnoty interesów. „Na przełomie stuleci Yuan był uważany za silnego człowieka, u którego obcy misjonarze, tak jak podczas powstania bokserów, szukali ochrony i na którym zagraniczni kupcy i rządy polegali odnośnie do pokoju i stabilności, uznawanych

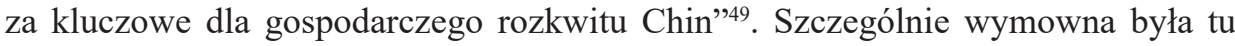
osoba sir Johna Jordana, posła JKM w Pekinie, dziekana korpusu dyplomatycznego i (co więcej niż pewne) najwybitniejszego obcego dyplomaty w Chinach. Wiązały go z Yuanem więzy osobistej przyjaźni - zjawisko bez precedensu w obliczu niemal absolutnej separacji Chińczyków i przybyszów na przełomie XIX i XX wieku. Krewki ulsterczyk uważał swego chińskiego druha za „człowieka najbardziej niezawodnego dla zabezpieczenia interesów tak chińskich, jak i brytyjskich" ${ }^{50}$. Późniejsze źródłowe rozprawy innych badaczy, w tym i piszącego te słowa, całkowicie potwierdziły ów obraz. Nawiasem mówiąc, choć interwencja obcych dyplomatów z Jordanem na czele w obronie Yuana, któremu po zgonie Cixi groziła śmierć, jest faktem nieulegającym wątpliwościsi ${ }^{51}$ jej rola była znacznie mniejsza, niż się to na ogół uważa.

${ }^{47}$ M. Nowikiewicz, Yuan Shikai jako reformator armii chińskiej u schyłku panowania dynastii Qing (1895-1908) [w :] Kadry decyduja o wszystkim. Studia z zakresu biografistyki wojskowej, red. J. Jędrysiak, D. Koreś, G. Strauchold, K. Widziński, „Wrocławskie Studia z Historii Wojskowości", t. 4, Wrocław 2015, s. 423-448.

${ }^{48}$ W. Rodziński, op. cit., s. 564. Od początku kariery Yuan jakoby wykorzystywał każdą ,sposobność [...] aby wkraść się w łaski obcokrajowców" (ibidem, s. 515).

${ }^{49}$ K.-Ch. Chan Lau, Anglo-Chinese Diplomacy in the Careers of Sir John Jordan and Yuan Shih-k'ai, 1906-1920, Hong Kong 1978, s. VII.

${ }^{50}$ Ibidem, s. VIII.

${ }^{51}$ Inspirowana przez Jordana nota korpusu dyplomatycznego znajduje się w: Jordan do Greya, 2 I 1909, TNA, FO 350/190 (papiery Jordana). Posłowie brytyjski, amerykański i niemiecki ostrzegali iż: China's foreign relations could suffer severely by a dimissal of a statesman who was universally considered the guarantee of his country political stability. 
Wirtuoz politycznych rozgrywek uratował się sam dzięki uruchomieniu koneksji na mandżurskim dworze ${ }^{52}$.

Ponadto już w połowie lat 60. XX wieku koreańsko-amerykański badacz Kwan-ha Yim udowodnił, z pełnym pokryciem źródłowym, zarówno stałe zwalczanie Yuana przez rząd i dyplomację japońską, jak i absolutnie decydującą rolę Tokio w katastrofie dyktatora w latach 1915-1916. Japończycy, nieznoszący Yuana od czasu, gdy jako przedstawiciel Qingów w Seulu skutecznie zwalczał poczynania wyspiarzy w Korei (1890-1894), działali tutaj dwutorowo. Z jednej strony uruchomili przeciw niedoszłemu cesarzowi osiadłych na Wyspach rewolucjonistów i wspomagali zbuntowanych generałów yuanowskiej Armii Beiyang, uświadamiając im, że wobec monarszych planów prezydenta znika szansa przejęcia po nim stanowiska głowy państwa. Z drugiej skutecznie oddziaływali na mocarstwa Ententy (którym japońskie wsparcie na morzu było niezmiernie potrzebne wobec szczytu zmagań w wojnie światowej), by nie poparły planów chińskiego przywódcy ${ }^{53}$.

Ustalenia Yima wykazały, że próba założenia przez Yuana nowej dynastii była przedsięwzięciem mającym wszelkie szanse powodzenia i unicestwiona została w znacznej części przez wrogie Chinom mocarstwo. Rzucało to dodatkowe, negatywne światło na skwapliwie przyjmujących pomoc z Tokio rewolucjonistów i generałów. Yuan tuż wcześniej, na początku 1915 roku, zdołał wszak dzięki uruchomieniu brytyjskiej odsieczy dyplomatycznej zneutralizować najbardziej złowrogie aspekty tak zwanych Dwudziestu Jeden Żądań, czyli podjętej przez gabinet Okumy Shigenobu próby obrócenia Chin w japoński protektorat. Zamyślał o symbolicznym wypowiedzeniu wojny Niemcom, co pozwoliłoby mu (za cenę oddania zasobów Chin do dyspozycji Ententy) wziąć udział w konferencji pokojowej i zażądać na niej - jako nominalny współkombatant - zwrotu Jiaozhou, niemieckiej enklawy w Chinach, przejętej w 1914 roku i okupowanej przez Japończyków ${ }^{54}$. Współreżyserowana przez wyspiarzy katastrofa 1916 roku plany te uniemożliwiła. Skrajnie negatywną postawę Japonii wobec Yuana i próby wykorzystania przeciw niemu sunyatsenowskich rewolucjonistów w czasie rewolucji Xinhai potwierdziły w tym samym mniej więcej czasie badania Ikeia Masaru ${ }^{55}$.

Niemalże równocześnie zmianie ulegać zaczął obraz Stu Dni Reform roku 1898, które dały Yuanowi pierwsze piętno w sławetnym tytule miguozei, „potrójnego zdrajcy". Postrzegane były one do tej pory jako szekspirowska tragedia reformatorów wiedzionych przez Kang Youweia, walczących z obskuranckim dworem cesarzowej wdowy Cixi, przy czym rolę Judasza sprzedającego swego mistrza cesarza (będącego formalnym przywódcą reformy) odegrać miał właśnie Yuan. Badania historyków,

${ }_{52}$ M. Nowikiewicz, Dyplomacja brytyjska wobec upadku Yuan Shikaia w 1909 r., „Dzieje Najnowsze" [artykuł w druku].

${ }^{53}$ K.-h. Yim, Yuan Shih-k'ai and the Japanese, „Journal of Asian Studies”, November 1964, vol. XXIV, no. 1, s. 63-73.

54 J. Polit, Odwrót znad Pacyfiku? Wielka Brytania wobec Dalekiego Wschodu, 1914-1922, Kraków 1999, rozdział III i IV (po latach uważam, iż w pracy tej byłem nazbyt krytyczny dla Yuana).

${ }_{55}$ M. Ikei, Japan's Response to the Chinese Revolution of 1911, „Journal of Asian Studies” 1966, vol. XXV, s. 213-227; J. Polit, Mocarstwa wobec rewolucji Xinhai, „Azja-Pacyfik”2011, nr 14, s. 96-106. 
takich jak Hua Siping, Luke S.K. Kwong czy Young-tsu Wong, ukazały, iż obraz ów opiera się nie na źródłach, a na wspomnieniach samego Kanga i jego uczniów, a w świecie zewnętrznym spopularyzowany został przez słynnego dziennikarza Johna Otway Percy'ego Blanda, przedstawiającego Cixi jako femme fatale schyłkowego Cesarstwa ${ }^{56}$. Autorzy ci, do których potem przyłączyli się inni badacze zachodni i tajwańscy, oskarżyli Kanga, że w zamian za zagraniczną pomoc gotów był wraz ze swymi kolegami przekształcić Chiny w luźną, zarządzaną przez mocarstwa federację, podporządkowaną cudzoziemskim doradcom, wśród których primus inter pares miał być były japoński premier Itō Hirobumi. Sprzeciwiający się im Yuan Shikai działałby więc z motywów patriotycznych, w interesie chińskiej racji stanu, do której odwoływała się broniąca całości państwa Cixi ${ }^{57}$.

Pewnym przyczynkiem do powstawania nowego obrazu Yuana stały się badania znakomitej francuskiej znawczyni dwudziestowiecznych Chin, Marie-Claire Bergère. Już w swym ciepło przyjętym studium o chińskim kupiectwie doby Republiki autorka ta dostrzegła osobisty wkład dyktatora w powodzenie ówczesnych przemian, sprzeczny z jego obiegowym wizerunkiem jako „tyrana anachronicznego". Według niej w wypadku Yuana ,autorytaryzm i nowoczesność były jedynie dwoma aspektami tej samej polityki, której celem pozostawało wzmocnienie siły państwa, rozważanej jako fundament narodowej jedności i dobrobytu" ${ }^{38}$. Natomiast w szeroko dyskutowanej biografii Sun Yatsena, napisanej z pewną sympatią dla tytułowego bohatera, ale także z wielkim (może nawet nadmiernym) krytycyzmem, przedstawiła w innym świetle poczynania ludzi uznawanych za bohatera i antybohatera republikańskiej rewolucji. Wskazując na fatalne błędy „Ojca Republiki” podczas pamiętnej jesieni i zimy przełomu lat 1911 i 1912, dowodziła, iż polityczny wzlot Yuan Shikaia

od początku wynikał z konsensusu, rozmyślnego wyboru dokonanego nawet przez południowców [to jest mieszkańców obszarów kontrolowanych przez zwolenników Suna - J.P.]. Yuan jawił się wszystkim jako człowiek zdolny do uporania się z kryzysem spowodowanym przez [republikańskie] powstanie z Wuchangu, do uzyskania abdykacji dynastii, uniknięcia wojny domowej i zachowania jedności narodowej na drodze zapobieżenia interwencji obcych mocarstw $^{59}$.

W istocie Sun wierzył w parlamentaryzm nie bardziej niż Yuan, był jednak nieskończenie mocniej oderwany od rzeczywistości. Dowiodło tego fiasko wznieconej

56 J.O.P. Bland, E. Backhouse, China under the Empress Dowager, Boston-New York 1914.

${ }^{57}$ L.S.K. Kwong, Chinese Politics at the Crossroads: Reflexions on the Hundred Days Reform of 1898, „Modern Asian Studies” 2000, vol. XXXIV, no. 3, s. 663-695 (Kwong powątpiewa w przywódczą rolę Kanga i jest znacznie bardziej radykalny niż w swej pierwszej pracy A Mosaic of the Hundred Days: Personalities, Politics and Ideas of 1898, Cambridge, MA 1984, passim, np. s. 213-221); S. Hua, The Meiji Restoration (1868) and the Late Qing Reform (1898) Revisited: Strategies and Philosophies, „East Asia. An International Quarterly", September 2003, vol. XXI, no. 3, s. 3-22; Y.-t. Wong, Revisionism Reconsidered: Kang Youwei and the Reform Movement of 1898, „,The Journal of Asian Studies”, August 1992, vol. LI, no. 3, s. 513-533. Przeciw tradycyjnej interpretacji wystąpił w 2004 r. tajwański historyk Lei Chia-sheng.

58 M.C. Bergère, L'age d'or de la bourgoisie chinoise, 1911-1937, Paris 1986, s. 207.

${ }_{59}$ M.C. Bergère, Sun Yat-sen, Paris 1994, s. 246-247. 
przezeń przeciw dyktatorowi „drugiej rewolucji” w 1913 roku, która obnażyła słabość jego społecznej bazy. Mimo to „odmówił uznania, że w 1913 roku słabość rewolucyjnej ideologii i organizacji były tak wielkie, że stawiały przed alternatywą: Yuan lub chaos" ${ }^{\circ 0}$.

Niejednoznaczne doświadczenia zamkniętego XX wieku kazały też inaczej spojrzeć na obraz Yuana jako grabarza raczkującej chińskiej demokracji. Prawda: chiński prezydent (naturalnie, w zaufanym gronie) nieraz szydził z parlamentaryzmu. „Parlament - zwierzał się swemu przyjacielowi, posłowi brytyjskiemu Jordanowi - to beznadziejne ciało. Ośmiuset ludzi! Dwustu jest dobrych, dwustu biernych, czterystu bezużytecznych. Cóż oni robią? Nie mogą się pogodzić nawet odnośnie do procedury obrad!"’1. Legislatywę skłonny był uważać co najwyżej za organ konsultacyjny, a do wzorów zagranicznych odnosił się ostrożnie. Zdarzyło mu się powiedzieć, iż „Republika Chińska to maleńkie dzieciątko. Należy je pielęgnować i strzec przed niestrawnymi posiłkami oraz silnymi lekarstwami przypisywanymi przez cudzoziemskich lekarzy" ${ }^{62}$. Jednakże, po pierwsze, nie ulegało wątpliwości, iż start chińskiego parlamentaryzmu zawdzięczać należy właśnie jemu. On bowiem był inicjatorem zwołania pierwszego zgromadzenia prowincjonalnego w Tianjinie, później zaś skutecznie zainspirował dwór qingowski do stworzenia dalszych. W 1909 roku ciała tego rodzaju zaczęto formować w stolicach pozostałych prowincji, w procesie dwuetapowym: w pierwszym $1,7 \mathrm{mln}$ wyborców wyłaniało elektorów na szczeblu powiatów (xian), ci zaś z kolei głosowali na 1643 posłów, którzy zebrali się w październiku w stolicach prowincji63. Po drugie zaś, oskarżenia były groteskowe, ponieważ pochodziły niemal wyłącznie od autorów uznających za rozsądne późniejsze, pochodzące to od sunyatsenistów, to (przede wszystkim) od komunistów, argumenty o niemożności szybkiej budowy ustroju konstytucyjnego w Chinach. Przykładowo, potępiający gwałtownie dyktaturę Czang Kaj-szeka (i sympatyzujący z komunistami) Lloyd Eastman przekonany był, że „demokracja w anglo-amerykańskim stylu nie była odpowiednia dla Chin" ${ }^{\circ 4}$. Przypomnieć warto w tym miejscu, iż pierwsze wolne wybory w - ograniczonej już tylko do Tajwanu - Republice Chińskiej odbyły się w 1991 roku. W ChRL nie nastąpiło to do dziś dnia, przy czym tamtejsi teoretycy, odwołujący się nie tyle do komunizmu, ile do konfucjanizmu, lubią wskazywać na „niemoralność” systemu parlamentarnego polegającą na tym, że „w demokracji większość może podjąć decyzję naruszającą moralność" ${ }^{65}$. Głoszący takie poglądy

${ }^{60}$ Ibidem, s. 276.

${ }^{61}$ Cyt. za: C. Pearl, Morrison of Peking, Sydney 1967, s. 289.

${ }^{62}$ Cyt. za: P. Reinsch, An American Diplomat in China, New York 1922, s. 3.

${ }^{63}$ R.R. Thompson, China's Local Councils in the Age of Constitutional Reform, 1998-1912, Cambridge, MA 1995.

${ }^{64}$ L. Eastman, The Abortive Revolution: China under Nationalist Rule 1927-1937, Cambridge, MA 1974, s. 180; przegląd tych poglądów daje Edmund S.K. Fung, In Search of Chinese Democracy, s. 7-14.

${ }^{65}$ M. Stepień, Chińskie marzenie o konstytucjonalizmie, Kraków 2015, s. 89. 
(okraszone informacjami o „malwersacji, kompromitacji i upadku neoliberalizmu”) przywódcy nie są jednak uważani za reakcyjnych, ale za nowoczesnych... ${ }^{66}$.

Rozmaite szczegółowe studia, składające się na kolejne kamyczki mozaiki, odkłamywały wiedzę o poszczególnych aspektach działalności dyktatora. Potwierdziło się na przykład, iż człowiek oskarżany powszechnie o zamiłowanie do rozkoszy stołu i łoża był pracoholikiem, „który jako urzędnik qingowski pozostawał w pracy od piątej rano do dziewiątej wieczór" ${ }^{\circ 7}$. Henrietta Harrison zwróciła uwagę na to, że w dobie przedstawiania złamanych w 1911 roku Mandżurów jako istnych dwunogich bestii Yuan w swych wystąpieniach w okresie rewolucji Xinhai nie odmalowywał nowej republiki jako świetlanych antypodów mandżurskiej tyranii, ale wskazywał (przynajmniej werbalnie), że powinna być ona wspólną ojczyzną Chińczyków Hanów (którym sam był) oraz innych narodów ${ }^{68}$. Zmiana perspektywy czasowej powodowała wreszcie odmienną interpretację „rewolucji” jako jedynego wartego uwagi i zbawiennego nurtu w nowoczesnej historii Chin. Z każdą nową publikacją na ten temat stawało się jasne, iż zainicjowana u schyłku dynastii, a sterowana głównie przez Yuana „Nowa Polityka” (Xinzheng) dała przemiany większe niż te, które nastąpiły po proklamowaniu Republiki w 1911 roku. Te ostatnie były w znacznej mierze kontynuacją dawnych reform, prowadzonych przez tego samego człowieka, tym razem występującego w roli prezydenta ${ }^{69}$. Interpretacje Younga i McKinnona uzyskały swe pełne potwierdzenie.

W 2004 roku na półkach księgarskich pojawiła się naukowa biografia Gu Wenjuna znanego jako Wellington Koo, powszechnie uważanego za jednego z najwybitniejszych dyplomatów chińskich XX wieku. Na początku swej długiej kariery ów wielokrotny minister spraw zagranicznych Republiki, będący w pewnym momencie p.o. premiera, sprawował też (jako bardzo młody człowiek) funkcję anglojęzycznego sekretarza prezydenta Yuana. Gloryfikujący wirtuoza negocjacji chińscy autorzy prześlizgiwali się zwykle nad tym epizodem jego życiorysu ${ }^{70}$. Dopiero amerykański biograf Stephen G. Craft (skądinąd często sceptyczny wobec swego bohatera) przytoczył jego refleksje na ten temat. „Yuan - wspominał Koo - poświęcał wiele uwagi sprawom polityki zagranicznej i uważał się za odpowiedzialnego za wszelkie poczynania rządu". W tej dziedzinie był jak najdalszy od wyprzedaży chińskich interesów na rzecz obcych mocarstw; przeciwnie, jego działania owocowały głębokim szacunkiem młodego sekretarza. W ocenie Koo „Yuan był człowiekiem wielkiej

${ }^{66} \mathrm{http}: / /$ przeglad-socjalistyczny.pl/recenzje/1556-xi (dostęp: 11.02.2020) (recenzja Andrzeja Zi emskiego ze zbioru myśli Xi Jinpinga Chińskie marzenie).

${ }^{67}$ D. Strand, An Unfinished Republic: Leading by Words and Deed in Modern China, Berkeley-Los Angeles-London 2011, s. 196.

${ }^{68}$ H. Harrison, The Making of a Republican Citizen: Political Ceremonies and Symbols in China, 1911-1929, New York 2000, s. 18.

${ }^{69}$ D.R. Reynolds, China 1898-1912: The Xinzheng Revolution and Japan, Cambridge, MA 1993; R.R. Thompson, The Lessons of Defeat; Transforming the Qing State after the Boxer War, „Modern Asian Studies", October 2003, vol. XXXVII, no. 4, s. 771 i n.

${ }^{70} \mathrm{~W}$ swej pracy V.K. Wellington Koo: A Case Study of China 's Diplomat and Diplomacy of Nationalism (Hong Kong 1981) Pao-chin Chu zrelacjonował lakonicznie (s. 9-10) ówczesne poczynania swego bohatera, nie wchodząc w niuanse relacji między nim a Yuanem. 
ambicji i zdecydowania, urodzonym przywódcą”, „człowiekiem czynu”, „dobrym administratorem". Ów nieznający języków obcych miłośnik konfucjańskich klasyków, który z Chin nie wyjechał dalej niż do Korei, w opinii absolwenta uniwersytetu Columbia był „nader nowoczesny, a nawet liberalny”, a choć autorytarny w działaniu, pozostawał ,patriotą w tym sensie, że w dziedzinie spraw zagranicznych był nader zazdrosny o chińską suwerenność" ${ }^{71}$. Wspomnienia byłego ministra potwierdziły dodatkowo to, co powoli przebijało się z innych relacji: oto Yuan był znakomicie poinformowanym, otwartym na inicjatywy podwładnych i niezmiernie przez nich lubianym szefem, o którym (notabene skłócony z nim potem) Liang Qichao zanotował, iż „przebywanie z prezydentem jest niczym nieustanne degustowanie szampana" 72 .

Powoli zmianie zaczął ulegać obraz Yuana w Chińskiej Republice Ludowej. Oficjalne ujęcie było nadal wysoce negatywne: zmuszała do tego, obok linii partii czerpiącej legitymację swej władzy z rewolucji, zbliżająca się stuletnia rocznica rewolucji Xinhai. Rewizji oficjalnego wizerunku w sferze literatury i filmu sprzyjała wszakże moda na historię, pozwalająca na częściową rehabilitację postaci niewalczących wprost przeciw komunistom (ci ostatni założyli swą partię w 1921 r., pięć lat po śmierci dyktatora). Yuan Shikai był postacią barwną, a jego głównym przeciwnikiem na arenie międzynarodowej byli Japończycy, przeciw którym rząd w Pekinie od czasu do czasu potrzebował historycznych argumentów (na przykład w reanimowanym od 2012 roku sporze o wyspy Senkaku, chiń. Diaoyu). Na początku stulecia wydano w ChRL w trzydziestu sześciu tomach (!) dzieła zebrane Yuana, zawierające tysiące oficjalnych dokumentów i osobistych listów. Zaczęto też pisać życzliwiej o jego przedrewolucyjnej działalności.

W 2018 roku, przeszło stulecie po śmierci, niedoszły cesarz doczekał się wreszcie nowej źródłowej biografii w języku angielskim. Stworzył ją pochodzący z ChRL, a pracujący w Stanach Zjednoczonych Patrick Fuliang Shan, profesor historii w Grand Valley State University w Allendale (stan Michigan).

Shan przypomniał o zasługach Yuana w dobie jego koreańskiej misji, która - jego zdaniem - opóźniła o dziesięć lat rosyjskie i japońskie próby podporządkowania sobie tego kraju. Podkreślił osobistą odwagę tego mniemanego tchórza, który podczas próby przewrotu pałacowego w Seulu 6 grudnia 1886 roku stał pod japońskim ostrzałem wśród padających żołnierzy, odmawiając wycofania się. Za to rolę generała odegraną w czasie Stu Dni Reform uznał za przesadzoną; Cixi i jej otoczenie i tak wiedzieli o skierowanych przeciw nim planom cesarza, niektórzy reformatorzy, jak Tan Sitong, zachowywali się jak „uzbrojeni szaleńcy”, a Yuan, mając tylko siedem tysięcy niedostatecznie uzbrojonych ludzi, nie mógł zmienić przebiegu wypadków. Biograf w całej rozciągłości podkreślił za to wagę przeprowadzanych przez generała odgórnych przemian (,rewolucji Xinzheng”) w ostatnich latach Cesarstwa. Ciekawe są rozważania odnośnie do przyczyny jego upadku w 1908 roku. Regent (który był bratem uwięzionego w 1898 roku cesarza Guangxu) mógł naturalnie szukać zemsty na Yuanie, tym bardziej że publikowane za granicą artykuły Kang Youweia

\footnotetext{
${ }^{71}$ S.C. Draft, V.K. Wellington Koo and the Emergency of Modern China, Lexington 2004, s. 33.

72 Cyt. za: E.P. Young, The Presidency of Yuan Shih-k'ai, s. 243.
} 
wyolbrzymiły rolę generała w wydarzeniach sprzed dziesięciu lat. Możliwe jednak, że przyczyną były związki Yuana z cudzoziemcami, a najpewniej chodziło o rewanż frakcji mandżurskiej, niechętnej bezprecedensowej karierze Chińczyka Hana. Na przymusowych wywczasach generał czytywał klasyków, ale także pomnażał majątek, inwestując w nowoczesny sektor gospodarki i dbając o edukację niezmiernie licznego potomstwa - także córek. „Był światły jak zwykle, co wykazał, wysyłając w 1911 roku synów na amerykańskie uczelnie, by otrzymali wykształcenie w zachodnim stylu" 73 .

Podczas rewolucji Xinhai Yuan okazał się człowiekiem opatrznościowym. Autor odwołał się tu do znanych argumentów, notabene zaskakująco rzadko cytując swych piszących po angielsku poprzedników, takich jak Young czy McKinnon. Jako bodaj pierwszy badacz wyraził też wątpliwości, czy prezydent naprawdę odpowiadał za skrytobójcze wyeliminowanie Song Jiaorena, oczywistego kandydata Kuomintangu na premiera po wyborczym triumfie tej partii w 1913 roku, choć użyte argumenty (iż Songa można było się pozbyć prościej środkami politycznymi) nieszczególnie przekonują. Wiarygodnie wyglądają natomiast dowody na kontynuację reform w czasie prezydentury. Terror Yuana po kuomintangowskiej próbie jego obalenia był faktem, ale jego rozmiary (tysiąc ofiar wobec ogromu Chin) nie zapowiadały koszmaru nadchodzącej epoki. Wobec drapieżnych zakusów Japończyków, których szczytem było Dwadzieścia Jeden Żądań, szef państwa opierał się, jak mógł, bezustannie broniąc chińskiej racji stanu. Jego pierwszym, ale katastrofalnym błędem była akcja monarchistyczna. Shan określił ją mianem „zagadkowej”, nie wykluczając inspiracji niemieckiej: wskazywał wszakże, iż mocarstwa, z fatalnym wyjątkiem Japonii, nie były jej przeciwne. Dorzucał też, z charakterystycznym dla chińskich badaczy potępieniem politycznego chaosu (chiń. luan) iż „wojna przeciw Yuanowi miała skutki obosieczne: położyła kres jego zabiegom o tron, ale także złamała mający tak długi historyczny precedens silny rząd centralny" "74.

P.F. Shan konkluduje, iż

Yuan Shikai i Sun Yatsen reprezentują dwie odmienne drogi do nowoczesnych Chin: Yuan był konserwatywnym reformatorem oraz modernizatorem; Sun radykalnym rewolucjonistą i także modernizatorem. To, że zwolennicy Suna poświęcali życie i rezygnowali z osobistego szczęścia, czyni ich bohaterami narodowymi. Niemniej celem Yuana była także modernizacja, acz osiągana w inny sposób.

Dyktatora zgubiło dążenie do tronu. „Zmierzające do tego celu wysiłki Yuana były jego błędem; stały się nie tylko jego osobistą tragedią, lecz także katastrofalnym nieszczęściem dla narodu" $"$.

Naturalnie: zaakceptowanie nawet wszystkich tez Shana nie będzie oznaczać pełnej rehabilitacji Yuan Shikaia w sensie, który niektórzy badacze postulują dla takich postaci, jak rzymski cesarz Galien czy angielski król Ryszard III. Chiński prezydent i niedoszły cesarz pozostanie już chyba na zawsze figurą kontrowersyjną. Nie ulega

\footnotetext{
${ }^{73}$ P.F. Shan, Yuan Shikai: The Reappraisal, Toronto 2018, s. 139.

${ }^{74}$ Ibidem, s. 230.

75 Ibidem, s. 9.
} 
wątpliwości, iż - mimo pozowania w zaciszu samotni w Danshang na zajętego wyłącznie studiowaniem klasyków konfucjańskiego mędrca - Yuan był człowiekiem żądnym władzy, uważającym podstęp i przemoc za całkowicie dopuszczalne sposoby uprawiania polityki (acz na pewno nie był w tym mniemaniu odosobniony). Mimo wszystko jest oczywiste, iż ponosił odpowiedzialność za skrytobójcze wyeliminowanie Song Jiaorena. Dzielił wszystkie ograniczenia swego wieku i klasy. Nie miał na przykład - podobnie jak ogromna większość współczesnych mu polityków chińskich (ale nie wszyscy!; do wyjątków należał jego własny wiceprezydent, Li Yuanhong) żadnego zrozumienia dla praw politycznych dla kobiet i nie widział potrzeby ich masowej edukacji. ( $Z$ drugiej jednak strony wszystkim swym córkom, których małżeństwa aranżował, zapewnił nowoczesne wykształcenie, łącznie z nauką języków obcych $^{76}$ ). Nie rozumiał też demokracji parlamentarnej i przekonany był, iż system ten nie może się przyjąć w Chinach. Przekonanie to, jak już jednak wspomniano, podzielają dziś jego następcy (uważani za niezwykle nowoczesnych...) dzierżący ster Państwa Środka.

Ostatecznie spór o Yuan Shikaia wpisuje się w odwieczny dylemat, znacznie starszy od czasów Księcia Machiavellego, a mianowicie czy postać zdobywająca władzę dzięki cynizmowi i zbrodniom może potem rządzić dobrze i sprawiedliwie. „Żaden rządzący, który postępowałby tak jak Yuan Shikai, nie byłby tolerowany w Europie ani Ameryce; w Japonii postradałby życie" - moralizatorsko oznajmił po zgonie dyktatora szef dyplomacji japońskiej Katō Takaaki ${ }^{77}$. Niemniej historycy, wskazujący choćby na Oktawiana Augusta, skłonni są niekiedy udzielać na wspomniane pytanie odpowiedzi twierdzącej. Poeci, jak Słowacki w swej Balladynie, ukazują raczej, że przekleństwo złego czynu pociąga za sobą owoce w postaci coraz to nowego zła.

\section{BIBLIOGRAFIA}

\section{Pamiętniki}

$\mathrm{Pu}$ Yi, Byłem ostatnim cesarzem Chin, tłum. J. Mach, Łódź 1988, t. I-II.

Reinsch P., An American Diplomat in China, New York 1922.

76 D. Strand, An Unfinished Republic, s. 133. szeroko o potomstwie Yuana, w tym o córkach, informują Sheau-yueh J. Chao i KaChuen Yuan Gee, Early Life of Yuan Shikai and the Formation of Yuan Family, Cuny Academic Works, https://academicworks.cuny.edu/bb_pubs/12 (dostęp: 15.02.2020). Yuan miał bliskie relacje przynajmniej z jedną z córek (trzecią), Yuan Shuzen; w 1916 r. była ona tą osobą z otoczenia dyktatora, która jako pierwsza powiedziała mu, że akcja monarchiczna przyniosła fiasko.

77 Notatka Morrisona z rozmowy z baronem Katō, w: Jordan do Greya, 20 IX 1916, NA, FO 405/220/208565. 


\section{Opracowania}

Bergère M.C., L'age d'or de la bourgoisie chinoise, 1911-1937, Paris 1986.

Bergère M.C., Sun Yat-sen, Paris 1994.

Bland J.O.P., Backhouse E., China under the Empress Dowager, Boston-New York 1914.

Chan Lau K.-Ch., Anglo-Chinese Diplomacy in the Careers of Sir John Jordan and Yuan Shih-k'ai, 1906-1920, Hong Kong 1978.

Chang C., The Third Force in China, New York 1952.

Chu P.-ch., V.K. Wellington Koo: A Case Study of China's Diplomat and Diplomacy of Nationalism, Hong Kong 1981.

Draft S.C., V.K. Wellington Koo and the Emergency of Modern China, Lexington 2004.

Fung E.S.K., In Search of Chinese Democracy; Civil Opposition in Nationalist China 1929-1949, Cambridge, MA 2000.

Chen Boda, Czan Kaj-szy, wrag kitajskogo naroda, Moskwa 1950.

Chen Yunqian, Sun Yat-sen jako symbol w pamięci politycznej klas niższych we współczesnych Chinach, „Azja-Pacyfik” 2011, nr 14, s. 49-69.

Ch'en J., Yuan Shih-k'ai 1859-1915: Brutus Assumes the Purple, London 1961.

Ch'i M., China Diplomacy 1914-1918, Cambridge, MA 1970.

Eastman L., The Abortive Revolution: China under Nationalist Rule 1927-1937, Cambridge, MA 1974.

China in Revolution: The First Phase, 1911-1913, ed. M.C. Wright, New Haven-London 1968.

Eminent Chinese of the Ch'ing Period (1644-1912), ed. A.W. Hummel, vol. I-II, Boston 1943, 1944.

Farjenel F., A travers la révolution chinoise. Mes séjours dans le sud et dans le nord. L'évolution des moeurs. Entretiens avec les chefs des partis. L'Emprunt inconstitutionel. Le coup d'état, Paris 1914.

Fung E.S.K., The Military Dimension of The Chinese Revolution: The New Army and its Role in the Revolution of 1911, Canberra 1981.

Harrison H., The Making of a Republican Citizen: Political Ceremonies and Symbols in China, 1911-1929, New York 2000.

Historia nowożytna Chin, red. S.L. Tichwiński, thum. M. Wolska, Warszawa 1979.

Hua S., The Meiji Restoration (1868) and the Late Qing Reform (1898) Revisited: Strategies and Philosophies, „East Asia. An International Quarterly”, September 2003, vol. XXI, no. 3, s. 3-22.

Ikei M., Japan's Response to the Chinese Revolution of 1911, „Journal of Asian Studies” 1966, vol. XXV, s. 213-227.

Jefimow G., Zarys nowożytnej i wspótczesnej historii Chin, tłum. M. Derenicz, Warszawa 1952.

Kadry decyduja o wszystkim. Studia z zakresu biografistyki wojskowej, red. J. Jędrysiak, D. Koreś, G. Strauchold, K. Widziński, „Wrocławskie Studia z Historii Wojskowości”, t. 4, Wrocław 2015.

Katkowa Z.D., Czudodiejew J., Kitaj-Japonia: liubow ili nienawist? K problemie ewolucji socjalno-psichologiczeskich i politiczeskich siereotypow wzaimowospijatija, Moskwa 2001.

Kwong L.S.K., Chinese Politics at the Crossroads: Reflexions on the Hundred Days Reform of 1898, „Modern Asian Studies” 2000, vol. XXXIV, no. 3, s. 663-695.

Kwong L.S.K., A Mosaic of the Hundred Days: Personalities, Politics and Ideas of 1898, Cambridge, MA 1984. 
Lary D., Yuan Shikai [w:] Encyclopedia of Modern China, vols I-IV, New York-San Francisco-New Haven, Conn - Wateville, Maine-London 2009, vol. IV, s. 132-134.

Lenin W.I., Diemokratia i narodniczestwo w Kitaje [w:] W.I. Lenin, Soczinenija, t. 18, Moskwa 1948.

McKinnon S.R., The Peiyang Army: Yuan Shih-k'ai and the Origins of Chinese Warlordism, „Journal of Asian Studies” 1973, vol. XXXII, no. 3, s. 405-422.

McKinnon S.R., Power and Politics in Late Imperial China: Yuan Shi-kai in Beijing and Tianjin, 1901-1908, Berkeley-Los Angeles-London 1980.

Niepomnin O.J., Istorija Kitaja. Epocha Cin, XVII - naczało XX wieka, Moskwa 2005.

Nowikiewicz M., Yuan Shikai jako reformator armii chińskiej u schytku panowania dynastii Qing (1895-1908) [w:] Kadry decyduja o wszystkim. Studia z zakresu biografistyki wojskowej, red. J. Jędrysiak, D. Koreś, G. Strauchold, K. Widziński, „Wrocławskie Studia z Historii Wojskowości”, t. 4, Wrocław 2015, s. 423-448.

Pearl C., Morrison of Peking, Sydney 1967.

Polit J., Mocarstwa wobec rewolucji Xinhai, „Azja-Pacyfik” 2011, nr 14, s. 87-106.

Polit J., Odwrót znad Pacyfiku? Wielka Brytania wobec Dalekiego Wschodu, 1914-1922, Kraków 1999.

Reynolds D.R., China 1898-1912: The Xinzheng Revolution and Japan, Cambridge, MA 1993.

Rodziński W., Historia Chin, Wrocław 1992.

Rozman G., Soviet Studies of Pre-Modern China, Assessments of Recent Scholarship, Ann Arbor 1984.

Shan P.F., Yuan Shikai: The Reappraisal, Toronto 2018.

Sharman L., Sun Yat-sen: His Life and Meaning, A Critical Biography, Stanford, CA 1934, reprint 1968.

Sheridan J.E., [recenzja z: E.P. Young, The Presidency of Yuan Shih-k'ai: Liberalism and Dictatorship in Early Republican China, Ann Arbor 1977], „The American Historical Review", February 1978, vol. LXXXIII, no. 1, s. 254-255.

Snow E., Red Star over China, New York 1936.

Stepień M., Chińskie marzenie o konstytucjonalizmie, Kraków 2015.

Strand D., An Unfinished Republic: Leading by Words and Deed in Modern China, Berkeley-Los Angeles-London 2011.

The Limits of Change: Essays on Conservative Alternatives in Republican China, ed. Ch. Furth, Cambridge, MA-London 1976.

Thompson R.R., China's Local Councils in the Age of Constitutional Reform, 1998-1912, Cambridge, MA 1995.

Thomps on R.R., The Lessons of Defeat; Transforming the Qing State after the Boxer War, „Modern Asian Studies”, October 2003, vol. XXXVII, no. 4, s. 769-862.

Tichwinskij S.L., Dwiżenije za reformy w Kitaje i Kan Ju-wej, Moskwa 1959.

Weale R.L.P., The Fight for the Republic in China, New York 1917.

Wong Y.-t., Revisionism Reconsidered: Kang Youwei and the Reform Movement of 1898, „The Journal of Asian Studies”, August 1992, vol. LI, no. 3, s. 513-533.

Yim K.-h., Yuan Shih-k'ai and the Japanese, „Journal of Asian Studies”, November 1964, vol. XXIV, no. 1, s. 63-73.

Young E.P., The Hung-hsien Emperor as Modernizing Conservative [w:] The Limits of Change: Essays on Conservative Alternatives in Republican China, ed. Ch. Furth, Cambridge MA-London 1976, s. 171-190.

Young E.P., Yuan Shih-k'ai Rise to the Presidency [w:] China in Revolution: The First Phase, 1911-1913, ed. M.C. Wright, New Haven-London 1968, s. 419-442.

Young E.P., The Presidency of Yuan Shih-k'ai: Liberalism and Dictatorship in Early Republican China, Ann Arbor 1977. 


\section{Strony internetowe}

Chao S-y. J., Gee KaChuen Yuan, Early Life of Yuan Shikai and the Formation of Yuan Family, Cuny Academic Works, https://academicworks.cuny.edu/bb_pubs/12 (dostęp: 15.02.2020).

\section{Wydawnictwa o charakterze informacyjnym}

Encyclopedia of Modern China, vols I-IV, New York-San Francisco-New Haven, ConnWateville, Maine-London 2009, vol. IV. 